\title{
STRATGI PARTAI PDIP DALAM PEMENANGAN PEMILU 2019 DI KECAMATAN DULUPI
}

\author{
Mahyudin Mursali' ${ }^{1}$, Sastro M Wantu ${ }^{2}$, Udin Hamim ${ }^{3}$ \\ Fakultas Ilmu Sosial, Universitas Negeri Gorontalo
}

(mahyudinmursali@gmail.com)

(sastrowantu@gmail.com)

(udinhamim@gmail.com)

\section{Info Artikel \\ Sejarah Artikel: \\ Diterima (Mei) (2021) \\ Disetujui (Juni) (2021) \\ Dipublikasikan (Juli) \\ (2021)}

Keywords:

Strategi Politik,

PDIP,

Pemenangan Pemilu

\begin{abstract}
Abstrak
Penelitian ini mengenai keingintahuan peneliti untuk menguak strategi apa yang dipakai partai PDIP dalam pemenangan pemilu 2019 khususnya di Kecamatan Dulupi. Penelitian ini bertujuan untuk mendeskripsikan bagaimana strategi politik PDIP dalam peenangan pemilu legislatif dan faktor-faktor apa saja yang mempengaruh kemenangan PDIP di Kecamatan Dulupi pada pemilu 2019. Jenis peneitian yang digunakan adalah kualitatif, dengan pendekatan deskriptif. Subjek penelitian yang dipilih secara purposive yaitu pengurus PDIP, para ASN di kecamatan Dulupi dan beberapa ketua-ketua Organisasi serta tokoh penting dalam masyarakat. Teknik pengumpulan data yang digunakan adalah dengan menggunakan metode wawancara, observasi, dan dokumentasi. Berdasarkan hasil penelitian ini terdapat tiga strategi yang dilakukan oleh PDIP dalam pemenangan Pemilu 2019 di kecamatan Dulupi yakni pertama startegi mobilisasi birokrasi, kedua strategi promosi calon kandidiat dan ketiga strategi jejaring sosial. kemudian faktor yang mempangaruhi atau mendukung strategi politik PDIP di kecamatan Dulupi yakni pertama modal kandidat, calon yang diangkat oleh PDIP di Kecamatan Dulupi mempunyai modal sosil dan modal capital yang sangat kuat. kedua keluaraga, keberdaan ikatan atau hubungan keluarga sangat erat antara calon dengan pemilih. Pemilih memilihcalon berdasarkan pada pertimbangan ikatan kekeluargaan.
\end{abstract}

\footnotetext{
${ }^{1}$ Mahasiswa Universitas Negeri Gorontalo

${ }^{2}$ Dosen Universitas Negeri Gorontalo

${ }^{3}$ Dosen Universitas Negeri Gorontalo
} 


\section{PENDAHULUAN}

Pemilihan umum ialah sarana untuk mewujudkan kedaulatan rakyat dalam pemerintahan Negara kesatuan republik Indonesia yang berdasarkan pancasila, sebagaimnana yang diamanatkan dalam Undang-Udang Dasar Negara Republik Indonesia 1945. Oleh karena itu, pemilu perlu diselenggarakan secara berkualitas dengan partisipasi rakyat seluas-luasnya dan dilaksanankan berdasarkan asas langsung, umum, bebas, rahasia, dan adil. Partisipasi rakyat dalam pemilu dapat diwujudkan dengan cara menjadi bagian dari instrument pemilu.

Seiring terjadinya perubahan sosial budaya masyarakat yang ditandai dengan semakin meningkatnya pemahaman politik rakyat, ketidakpuasan terhadap kelemahan sistem pemilu semakin mencuat. Hal ini disebabkan pelaksaan para aparat pelaksana pemilu di Indonesia tidak berdasarkan pada semanagat kejujuran dan keadilan.Persoalan terbesar adalah adanya kerengganagan (jarak) antara wakil terpilih dengan rakyat pemilih di daerah pemilihan masingmasing.Layaknyanya Pemilu adalah bagian dari implementasi daulat rakyat yang dilaksanakan selama lima tahun untuk menentukan kuasa yang didaulatkan oleh rakyat.

Dengan demikian, Pemilu merupakan bagian dari narasi demokrasi yang dijalankan oleh Negara sebagai bagian dari proses kedaulatan warga bangsa. Realitas menunjukan, ketidakpuasan masyarakat pasca Pemilu merupakan hal yang tidak bisa dielakkan.Sebahagian besar anggota DPRD mengingkari janji politik serta kebiasaan pola perilaku yang jauh berbeda dengan masa kampanye politik.Upaya untuk mengubah jarak antara wakil terpilih dengan rakyat dilakukan oleh parah calon legislative dari berbagai partai politik dengan berupaya menarik simpati dari rakyat.Pendekatan dilakukan oleh para calon, mulai dari kampanye terbuka, pendekatan secara personal, bahkan ada yang menggunakan politik uang sebagai alat untuk membeli suara.

Peta politik Kabupaten Boalemo pada Pemilu 2019 mengalami perubahan signifikan. Sejak Pemilu sebelumnya, Partai PDIP hanya memiliki 3 (tiga) Kursi, yakni Dapil 1 Tilamuta, Botumoito, Mananggu 1 Kursi; Dapil 2 (dua) Dulupi, Wonosari 2 (dua) kursi dan Dapil 3 Paguyaman, Paguyaman Pantai tidak memperoleh Kursi di DPRD Kabupaten Boalemo. Sementara partai pemenang pada Pemilu sebelumnya adalah 
partai Golkar. Namun demikian, pada Pemilu 2019 PDIP sebagai partai pemenang dengan jumlah 7 Kursi dengan alokasi Dapil 1 sebanyak 2 (dua) kursi; Dapil 2 (dua) sebanyak 3 (tiga) kursi dan Dapil 3 (tiga) 2 Kursi. Data tersebut menunjukan hamper semua Dapil ada ketambahan 1 (satu) kursi dan khusus untuk Dapil 3 (tiga) memperoleh 2 (dua) Kursi. Hal yang sama berlaku juga pada pemilihan anggota DPRD Provinsi yang salama ini hanya 1 (satu) kursi menjadi 2 (dua) Kursi di Kabupaten Boalemo.

Data di atas menunjukan strategi partai politik PDIP menjelang Pemilu 2019 sangat efektif dalam pemenangan partai politik di Kabupaten Boalemo.Sesuai dengan data observasi awal menunjukan ada beberapa strategi politik yang dilakukan oleh PDIP di Dapil 2 (dua) Dulupi dan Wonosari.Pertama, strategi melaui mobilisasi birokrasi,Kedua, Kandidat, strategi promosi kandidat sangat efektif dalam mendulang suara di Dapil II Dulupi- Wonosari, hal ini dibuktikan dengan selainpethana, PDIP ada ketambahan 1 kursi di Dapil 2.Ketiga, program Kerja, selain kandidat calon, program kerja sangat efektif sebagai bagian dari strategi politik PDIP di Kecamatan Dulupi. Salah satu program kerja calon dan partai yang dinilai sangat efektif adalah kewajiban pembayaran Pajak Bumi dan Bangunan (PBB).

Dengan demikian kemenangan partai PDIP dalam pemilu 2019 di Kabupaten Boalemo khususnya di Kecamatan Dulupi tidak terlepas dari strategi yabg dibuat oleh partai tersebut. Strategi yang dilakukan oleh PDIP dalam upaya pemenangan legislatif tahun 2019 dilakukan secara kelembagaan, yaitu strategi partai dalam memenagkan pemilu maupun strategi yang dilakukan secara personal oleh para calon legislative.

\section{METODE PENELITIAN}

Jenis penelitian yang digunakan dalam penelitian ini adalah dengan metode penelitian deskriptif kualitatif. Penelitian ini selain dilakukan proses pengambilan data juga dituntut penjelasan yang berupa uraian dan analisis yang mendalam. Penelitian berupa deskriptif diharapkan hasilnya mampu memberikan gambaran riil mengenai kondisi dilapangan tidak hanya sekedar sajian data.

\section{HASIL PENELITIAN}


TabelMatrik Strategi Politik Dan Faktor Yang Mempengaruhi Partai PDIP Dalam Pemenangan Pemilu 2019 di Kecamatan Dulupi

\begin{tabular}{|c|c|c|}
\hline No & Masalah & Temuan Hasil \\
\hline \multicolumn{3}{|c|}{ Strategi Politik PDIP Dalam Pemenangan Pemilu 2019 di Kecamatan Dulupi } \\
\hline 1 & Strategi Mobilisasi Birokrasi & $\begin{array}{l}\text { Mesin mobiliasi birokrasi menjadi } \\
\text { kekuatan bagi PDIP dalam memenangkan } \\
\text { pertarugan di Kecamatan Dulupi }\end{array}$ \\
\hline 2 & Promosi Calon Kandidat & $\begin{array}{l}\text { Penjaringan dan penetapan calon } \\
\text { mengedepankan aspek opini masyarat } \\
\text { terhadap calon kandidat. keberadaan } \\
\text { Harijanto Mamangkey dan Rensi Makuta } \\
\text { memiliki nilai promosi yang tinggi bagi } \\
\text { masyarakat di Kecamatan Dulupi }\end{array}$ \\
\hline 3 & Jejaring Sosial & $\begin{array}{l}\text { Jejaraing sosial yang dimiliki oleh kedua } \\
\text { calon terebut terdiri dari beberapa aspek } \\
\text { dianataranya, jaringan parti hingga pada } \\
\text { tingkat dusun, keluarga dan kerabat, } \\
\text { kelompok usaha, keterlibatan petani }\end{array}$ \\
\hline \multicolumn{3}{|c|}{ Faktor Pendudkung } \\
\hline 1 & Modal Kandidat & $\begin{array}{l}\text { Kedua kandidat tersebut memiliki modal } \\
\text { sosial dan modal capital yang sangat kuat } \\
\text { sehingga menjadi tokoh sentral di } \\
\text { kecamatan Dulupi. Atas modal tersebut } \\
\text { membuat popularitas, image dan citra } \\
\text { calon kandidat sangat digemari oleh } \\
\text { masyarakat pemilih }\end{array}$ \\
\hline 2 & Keluaraga & $\begin{array}{l}\text { Faktor keluraga mendukung modal sosai } \\
\text { dan modal capital calon. Rensi Makuta } \\
\text { selain dari faktor modal, didukung oleh } \\
\text { ikatan keluarga. Sementara itu. Pemilih } \\
\text { yang memilih Harijanto Mamangkey }\end{array}$ \\
\hline
\end{tabular}




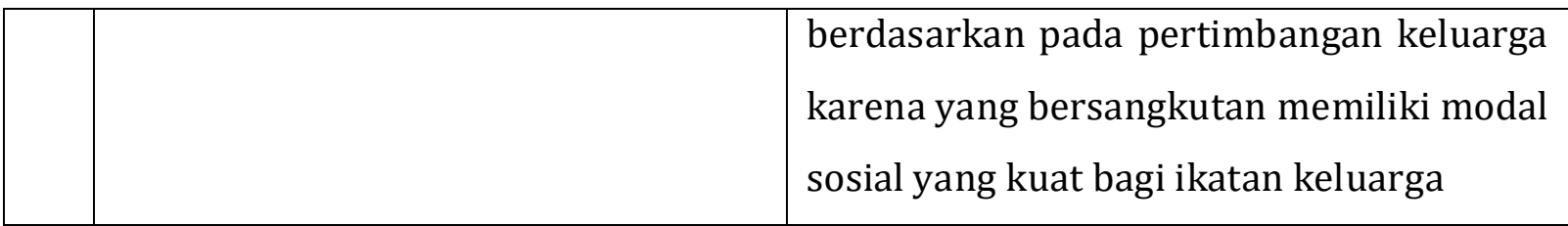

Berdasarkan pada matrik temuan hasil penelitian di atas, kerangka teori yang digunakan penulis dalam menganalisis temuan tersebut berdasarkan pada apa yang di kemuakkan oleht Nursal (dalam Firmanzah, 2007 : 15-16) tentang strategi marketing politik calon antara lain:

a) Pemasaran produk dan promosi politik calon kandidat secara langsung kepada calon pemilih (push political marketing), strategi ini lebih berfokus pada isuisu yang penting bagi para electorate dan bukan hanya menjual kandidat atau partai sebagai komoditas, namun pesan dalam bentuk komunikasi politik baik ferbal maupun non-ferbal menajdi prioritas calon maupun partai politik. Calon sebagai produk yang mampu menjawab kebutuhan masyarakat pemilih akan lebih efektif jika dibandingkan dengan cara lain. Dengan melakukan penjaringan, seleksi dan penetapan calon oleh PDIP di Kecamatan Dulupi lebih memprioritaskan opini dan tuntutan masyarakat pemilih. Keberadaan Harijanto Mamangkey dan Rensi Makuta sebagai figure dan tokoh sentaral di kecamatan Dulupi sesuai denga kebutuhan dan opini masyarakat yang berkeambang pada saat pemilu.

b) Strategi melalui kelompok, tokoh atau organisasi yang berpengaruh (pass poolitical marketing). Pada strategi ini pesan disampaikan melalui individu, kelompok maupun organisasi yang mempunyai pengaruh. Cara-cara pendekatan dan lobbying pada strategi ini perlu disesuaikan dengan tipe - tipe individu, kelompok dan organisasinya. Ada dua strategi PDIP dalam pemenangan calon pada strategi ini yakni strategi mobilisasi birokrasi dan penguatan jejaraing sosial. Strategi mobilisasi birokrasi sangat efektif, hal ini bukan hanya terjadi di kecamatan Dulupi, namun Boalemo secara keseluruhan, dimana PDIP keluar sebagai partai pememang dengan junlah kursi 7 suara. Selai itu melalui jaringan sosial calon kandidat mendukung stratgi PDIP pada Pemilu 2019.

c) Faktor modal sosial dan modal capital Harijanto Mamangkey dan Rensi Makuta menjadi pertimbangan khusus bagi pemilih dalam menentukan pilihan politik. 
Dengan kekuatan modal calon kandidat, popularitas, image dan citra calon kandidat menajadi sasaran bagi partai politik dalam memenangkan calon dan partainya. Popularitas kanddiat calon adalah bagian terpenting dalam strategi marketing politik, hal ini didukung oleh modal sosial dan capital dari kedua calon tersebut. terbentuknyaimage dan citra kandidat juga tidak terlepas dari modal kandidat calon, hal ini akan terbentuk dengan sendirinya jika calon kandidat dalam kehidupan sehari-hari mampu menguatkan modal sosailnya kepada masyarakat pemilih. Selain faktor modal, keberadaan keluarga menjadi faktor penentu pemilih dalam menentukan pilihan dan dukungan politik. Kedekatan secara emosinal akan mengikat psikologi pemilih dengan kanddiat.

\section{KESIMPULAN}

Berdasarkan pada temuan hasil dan pembahasan menganai strategi politik PDIP dalam pemenangan Pemilu di Kecamatan Dulupi di atas, penulis dapat menarik kesimpulan bahwa ;

a. Terdapat tiga strategi yang dilakukan oleh PDIP dalam pemenangan Pemilu 2019 di kecamatan Dulupi diantaranya; 1) startegi mobilisasi birokrasi, dengan memanfaatkan mesin birokrasi membuat partai dan calon dapat memenangkan pertarungan di saat pemilu. 2) strategi promosi calon kandidiat, langkah awal melalu proses penjaringan hingga pada penetapan calon sesuai dengan kebutuhan masrakakat, dimana calon kandidat yang disodorkan kepada masyarakat penilih memiliki reputasi dan kapasitas yang tinggi di hadapan masyarakat pemilih, hal ini yang kemudian membuat proses promosi produk partai melalaui calon didukung dan dipilih oleh masyarakat. 3) Strategi jejaring sosial, dengan memanfaat seluruh akses yang dimiliki oleh partai sampai pada tingkat ranting membantu partai dalam menjankan strategi politiknya, selain itu jaringan calon memalui keluarga, kelompok usaha, petani dan lainnya efektif dalam perolehan suara calon maupun partai.

b. Faktor yang mempangaruhi atau menudukung strategi politik PDIP di kecamatan Dulupi terdiri dari ; 1) Modal kandidat, calon yang diangkat oleh PDIP di Kecamatan Dulupi mempunyai modal sosil dan modal capital yang sangat kuat. Modal tersebut sangat mempengaruhi popularitas, image, dan citra calon 
kandidat yang diusung. 2) Keluaraga, keberdaan ikatan atau hubungan keluarga sangat erat antara calon dengan pemilih. Pemilih memilih calon berdasrkan pada pertimbangan ikatan kekeluargaan. Fenomena lain juga menunjukan, tanpa ikatan keluarga, namun calon yang memiliki modal sosial denggan keluarga efektif dalam memeberiakn dukungan dan pilihan politik.

\section{DAFTAR PUSTAKA}

Arbi Sanit, 1985. PerwakilanPolitik di Indonesia, Jakarta : CV. Rajawali

Adman Nursal, 2004. Political Marketing :Strategime menangkan pemilu, sebuah pendekatan baru kampanye pemilihan DPR, DPD, Presiden, Jakarta : PT Gramedia Pustaka Utama,

Fandi Tjiptono, 2000. Strategi Pemasaran, Cet. Ke-II. Yogyakarta: Andi

Firmanzah, 2007. Mengelola Partai Politik: Komunikasi dan Positioning Ideologi Politik di Era Demokrasi. Jakarta: Yayasan Obor Indonesi

Miriam Budiarjo, 2003. Dasar-Dasar Ilmu Politik. Jakarta: Gramedia Pustaka Utama Tahun 2008. Dasar-Dasar Ilmu Politik.Jakarta : PT.Gramedia Pustaka Utama,

Muchamad Ali Safa"at, 2011.Pembubaran Partai Politik: Pengaturan dan Praktik Pembubaran Partai Politik Dalam Pergulatan Republik, Jakarta: Rajawali Pers

Ramlan Surbakti, 1992. Memahami Ilmu Politik. (Jakarta, PT . Gramedia Widisuasarana. 1999. Memahami Ilmu Politik, Jakarta: PT Grasindo

Sidarta GM, 2008. Strategi Pemenangan dalam Pemilihan Langsung. Ciputat : Kalam Pustaka 